\title{
A NEW SPECIES OF NICOLETIIDAE (INSECTA: ZYGENTOMA) FROM KARTCHNER CAVERNS STATE PARK, ARIZONA
}

\author{
Luis Espinasa ${ }^{1 *}$, Robert B. Pape², Alanna Henneberry ${ }^{1}$, And Christopher Kinnear ${ }^{1}$
}

\begin{abstract}
Speleonycta anachoretes, n. sp., is described and differentiated from $S$. ozarkensis, known from caves in the Ozark Plateau. The new species was collected from Kartchner Caverns State Park in Arizona. Morphology and preliminary analyses using 16S rRNA corroborate that Speleonycta may be related to Texoreddellia, another nicoletiid genus from caves of Texas and northern Mexico. General information regarding its conservation status within the commercial cave is provided.
\end{abstract}

\section{INTRODUCTION}

While insects of the family Nicoletiidae are among the most important and common representatives of caveadapted fauna in the neotropics (Espinasa and Giribet, 2009), they have a limited presence in caves of northern latitudes. Texas has a complex of at least six species in the genus Texoreddellia (Espinasa and Giribet, 2009), and specimens collected from several Ozark caves in Arkansas and Oklahoma were recently described under a new genus, Speleonycta (Espinasa et al., 2010).

The cave system of Kartchner Caverns is in an isolated outcrop of limestone near the base of the Whetstone Mountains southwest of Benson, Arizona (Jagnow, 1999). The Kartchner Caverns system was discovered in 1974 and was kept in nearly pristine condition (Tuffs and Tenen, 1999). In 1988 the state of Arizona purchased the cave as a state park and developed it into one of the top show caves in the US, with conservation of the resource as its top priority. As part of the pre-development studies, Welbourn (1999) conducted an inventory of the invertebrate cave fauna between 1989 and 1991. In that study, he observed three individual nicoletiids and reported them as Nicoletia sp., but studied them no further.

Under the auspices of Arizona State Parks, we are conducting a re-inventory of the invertebrate fauna to analyze its current status and identify changes that have occurred in the invertebrate ecology of the cave over the twenty years since the original inventory, including ten years of post-development visitation. Several nicoletiid specimens were collected, their relatively abundance was assessed, and they are described here as a new species using morphologic and DNA data. Genus assignment is also corrected, as they belong to Speleonycta and not to Nicoletia.

\section{Material AND Methods}

Dissections of a paratype were made with the aid of a stereo microscope and mounted as fixed preparations with
Cytoseal 60 solution (Richard-Allan Scientific). The remaining samples were left in vials with ethanol. Illustrations were made with the aid of a camera lucida attached to a microscope. Specimens will be deposited in a collection at the American Museum of Natural History in New York.

A DNA sample was extracted using Qiagen's DNEasy Tissue Kit by digesting a leg in lysis buffer. Amplification and sequencing of the 16S rRNA fragment was done as in Espinasa and Giribet (2009) following standard protocols and primers used in the past for nicoletiids. Chromatograms obtained from the automated sequencer were read and contigs made using the sequence-editing software Sequencher 3.0. External primers were excluded from the analyses. Sequences were aligned and neighbor-joining analysis was performed with ClustalW2.

Population density was roughly assessed by counting the number of animals observed in four days of observations divided by the area of the floor (including habitat under rocks) that was accessible for direct examination in the small, approximately $20 \mathrm{~m}$ long Jackrabbit Gallery.

\section{RESULTS}

Molecular data were obtained from the Kartchner Caverns nicoletiid and from S. ozarkensis. The 16S rRNA fragments were $496 \mathrm{bp}$ long (primers excluded). Using these same sequences of $16 \mathrm{~S}$ rRNA fragments of twenty-three species within the subfamily Cubacubaninae, Espinasa and Giribet (2009) observed that pairs of specimens within a population differ by an average of 1.8 nucleotides $( \pm 2.2$ stdev; range 0 to $7 ; \mathrm{n}=26$ ), by 2.3 nucleotides ( \pm 1.9 stdev; range 1 to $6 ; \mathrm{n}=9$ ) in different populations of the same species, and by 54.7 nucleotides ( \pm 9.5 stdev; range 45 to 64 ; $\mathrm{n}=3$ ) among sister species. Nucleotide alignment of the Kartchner Caverns specimen with $S$. ozarkensis showed considerable sequence difference (65 bp, 13.1\%; Table 1),

\footnotetext{
*Corresponding Author, luis.espinasa@marist.edu

${ }^{1}$ School of Science, Marist College, 3399 North Road, Poughkeepsie, NY 12601

${ }^{2}$ University of Arizona, Department of Entomology, Tucson, AZ 85721
} 
Table 1. Alignment of the 16S rRNA fragment sequences of Speleonycta ozarkensis and $S$. anachoretes n. sp. showed considerable sequence difference (65 bp; $13.1 \%)$.

\begin{tabular}{|c|c|}
\hline Species & $16 \mathrm{~S}$ rRTA Fragn ent Sequence \\
\hline $\begin{array}{l}\text { S._- _arkensis } \\
\text { S._anachoretes }\end{array}$ & 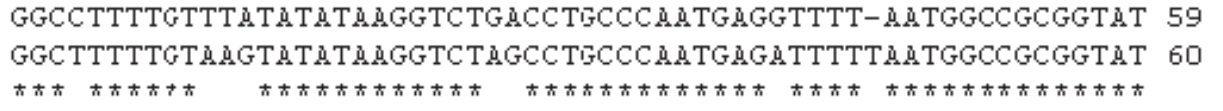 \\
\hline 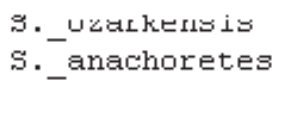 & 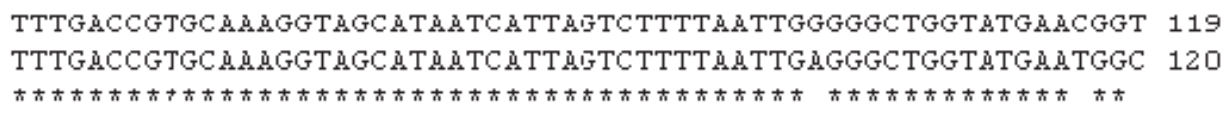 \\
\hline $\begin{array}{l}\text { 5._øaarkensis } \\
\text { 5._anachoretes }\end{array}$ & 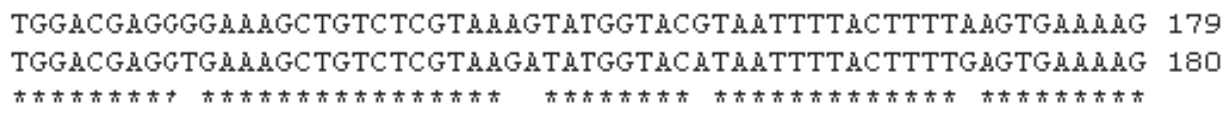 \\
\hline $\begin{array}{l}\text { 5._ozarkensis } \\
\text { 5._anachoretes }\end{array}$ & 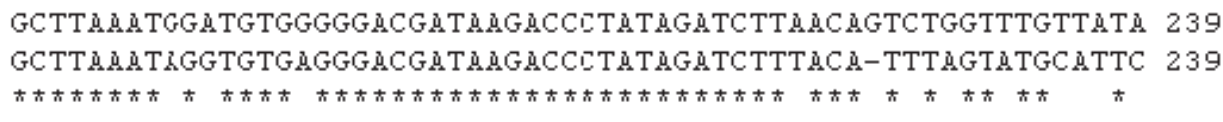 \\
\hline $\begin{array}{l}\text { s._-aarkensis } \\
\text { s._anachoretes }\end{array}$ & 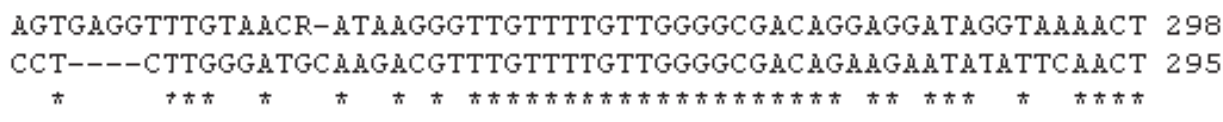 \\
\hline $\begin{array}{l}\text { S._qaarkensis } \\
\text { S._anachoretes }\end{array}$ & 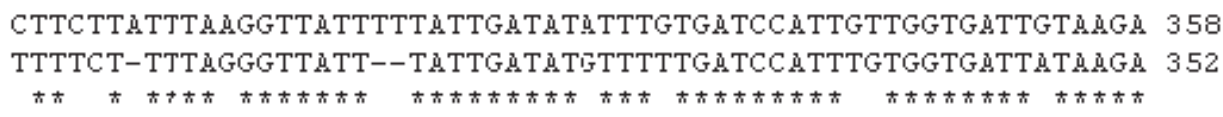 \\
\hline $\begin{array}{l}\text { s._-zarkensis } \\
\text { s._anachoretes }\end{array}$ & 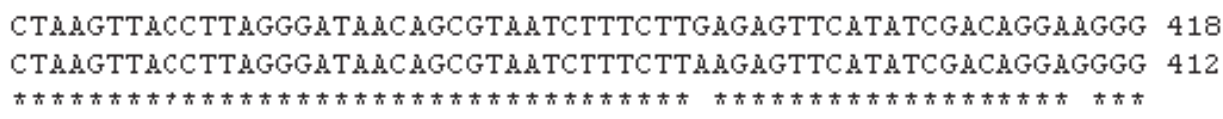 \\
\hline $\begin{array}{l}\text { s._-zarkensis } \\
\text { s._anachoretes }\end{array}$ & 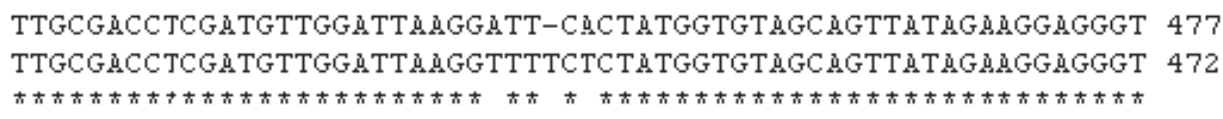 \\
\hline $\begin{array}{l}\text { S._øairkensis } \\
\text { s._anachoretes }\end{array}$ & 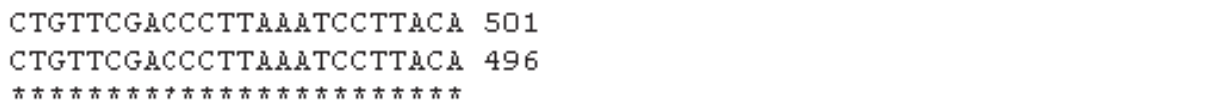 \\
\hline
\end{tabular}

supporting the hypothesis that they belong to separate species. A neighbor-joining tree showed the new species and S. ozarkensis clustered together. Both species of Speleonycta are then shown to be within a monophyletic group with Texoreddellia, at the exclusion of other genera of the Cubacubaninae and in agreement with previous histone sequence data of S. ozarkensis (Espinasa et al., 2010). Nevertheless, these results should be considered as preliminary. Establishing the phylogeny of the group and assessing whether Speleonycta and Texoreddellia should be placed in a new subfamily are the aim of current research using data from additional molecular markers.

New Species: Speleonycta anachoretes Espinasa, Pape, Henneberry, and Kinnear (Figs. 1, 2A-J, 3A-F)

\section{Material}

Holotype male, body $12.7 \mathrm{~mm}$, tarsus $3^{\text {rd }}$ leg $1.4 \mathrm{~mm}$. Paratypes: Males 7.5, 6.5, and $6.2 \mathrm{~mm}$; Females 15, 11, and
$10.5 \mathrm{~mm}$; Juvenile $5 \mathrm{~mm}$. Kartchner Caverns, Kartchner Caverns State Park, Cochise County, Arizona. $31^{\circ} 50^{\prime} 16^{\prime \prime} \mathrm{N}$ $110^{\circ} 21^{\prime} 05^{\prime \prime}$ W. $3 / 14-18 / 10,1 / 9 / 10$ and $11 / 27 / 09$.

\section{Other locality}

Speleonycta sp. - Arkenstone Cave, Colossal Cave Mountain Park. Pima County, Arizona. $32^{\circ} 02^{\prime} \mathrm{N}$ $110^{\circ} 35^{\prime} \mathrm{W}$. Male $9.4 \mathrm{~mm}$; Female $9.9 \mathrm{~mm}$.

\section{Description}

Maximum body length of samples $15 \mathrm{~mm}$. Maximum conserved length of antennae and caudal appendages $15 \mathrm{~mm}$ and $12 \mathrm{~mm}$ respectively. When complete, their length is only slightly longer than body. General color light yellow to white. Body proportions as in Figure 1.

Head with macrochaetae and microchaetae as shown in Figure 2A, with about seven macrochaetae on border of insertion of antennae. Pedicellus of male shorter than first 


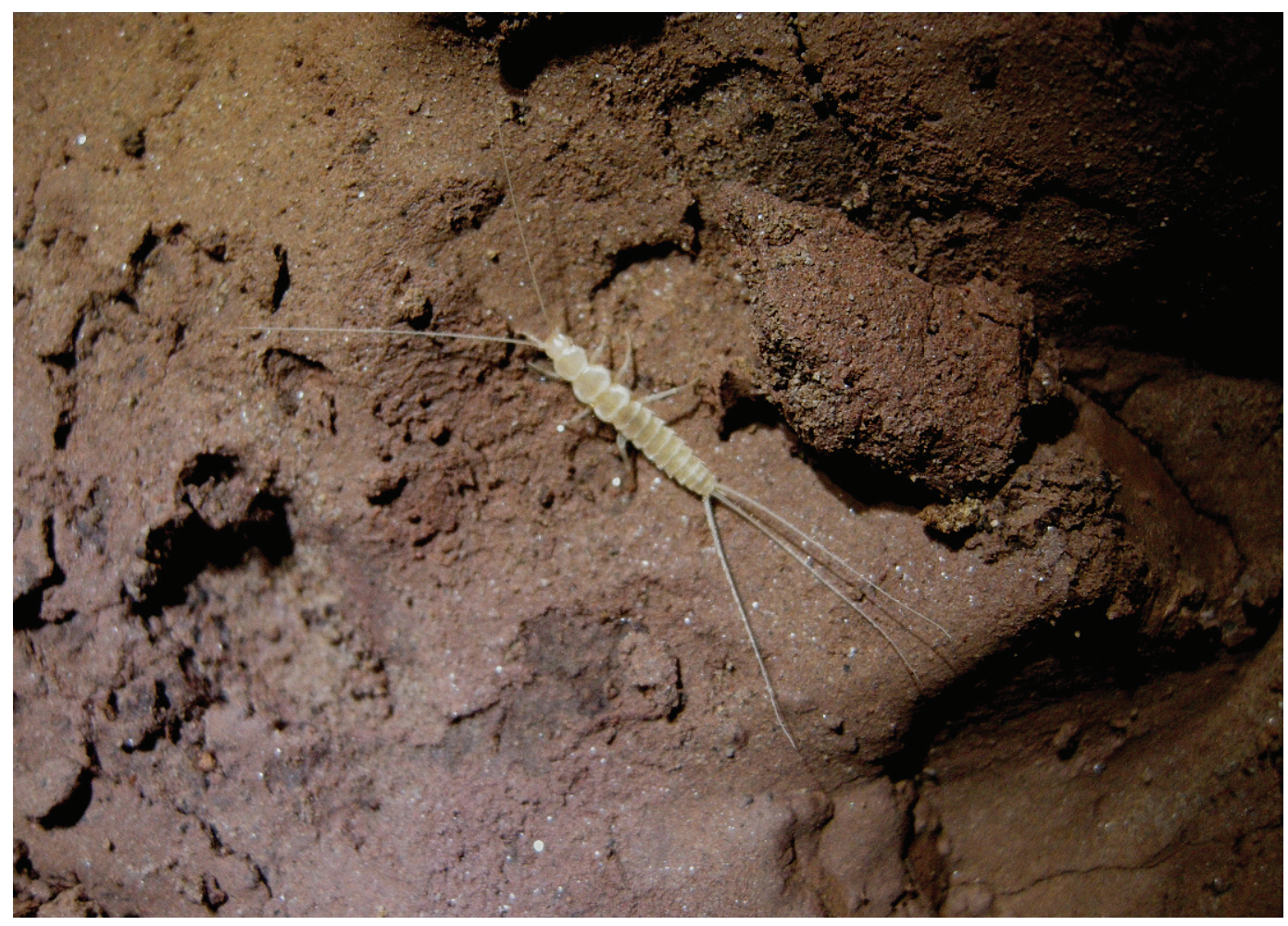

Figure 1. Speleonycta anachoretes $\mathbf{n}$. sp. Live specimen from Kartchner Caverns.

article and with clusters of unicellular glands. Four ventral clusters are bordered with a not very conspicuous row of microchaetae forming a U (Fig. 2B) and, on outer border, a blade-like cusp not very sclerotized and with more unicellular glands at its base (Fig. 2B-C), similar to Speleonycta ozarkensis. Basal articles of antennae of female simple.

Mouthpart appendages short, especially when compared with other cave nicoletiid species. Labial palp as in Figure 2D, apical article distinctly longer than wide and longer than the penultimate article. Penultimate article with a not very distinct bulge containing two macrochaetae. Labium and first article of the labial palp with macrochaetae. Maxilla as shown in Figure 2E. Last article only slightly longer than penultimate in large individuals, but in small ones it can be $1.5 \times$. Apex of galea with two conules, one longer than wide and the other slightly wider than long (Fig. 2F). Two teeth on lacinia. Mandible chaetotaxy as in Figure 2G, with five or six macrochaetae. Pro-, meso-, and metanota with several macrochaetae on postero-lateral margins, apart from several setae of varied sizes (Fig. 2H). Legs long, hind tibia about $5 \times$ longer than wide and slightly shorter than tarsus (Fig. 2I). Juveniles with thinner legs. On largest male $(12.7 \mathrm{~mm})$, tibia of second leg without the large bulge or modified macrochaetae found in S. ozarkensis. Female legs also simple. Claws short and with a hairy appearance similar to $S$. ozarkensis.

Abdominal terga as in Figure 3A, with multiple macrochaetae of varied sizes on their edges and $1+1$ distinct macrochaetae within the surface of the terga. Speleonycta ozarkensis also has these distinct macrochaetae, but they were not mentioned or represented in the original description. Abdominal sterna as in Figures $2 \mathrm{~J}$ and 3B. Urosterna I entire and II-VII subdivided into two coxites and one sternite. Urosterna VIII and IX of male entire. Urosternum III and IV of adult male apparently without modifications. Posterior margin of urosternum VIII of male straight, without emarginations or projections in between the stylets of this segment (Figs. 3B and 3G). Urosternum IX of male as in Figures 3B (Kartchner specimen) and $3 \mathrm{G}$ (Arkenstone specimen). Point of insertion of paramera in urosternum IX slightly below level of base of the stylets of this segment. Base of internal faces of coxal processes with one slightly sclerotized macrochaeta (Figs. 3B and 3G). Penis and paramera as in Figures 3B and 3G. Paramera very stout, with a distal semi-eversible vesicle and with long specialized macrochaetae, somewhat similar to $S$. ozarkensis. Paramera attain about half the length of stylets IX.

Stylets IX stout and without small teeth on robust terminal spine. Stylets IX larger than others, without sensory cones, but with some sclerotized macrochaetae of varied sizes (Fig. 3G), ventrally with about five macrochaetae (Fig. 3B). Other stylets have a terminal spine with small teeth and with about four macrochaetae (Fig. 3B). Urotergite X protruding, shallowly emarginate in both sexes, posterior angles with several macrochaetae and a few relatively strong setae (Fig. 3D). Length of 

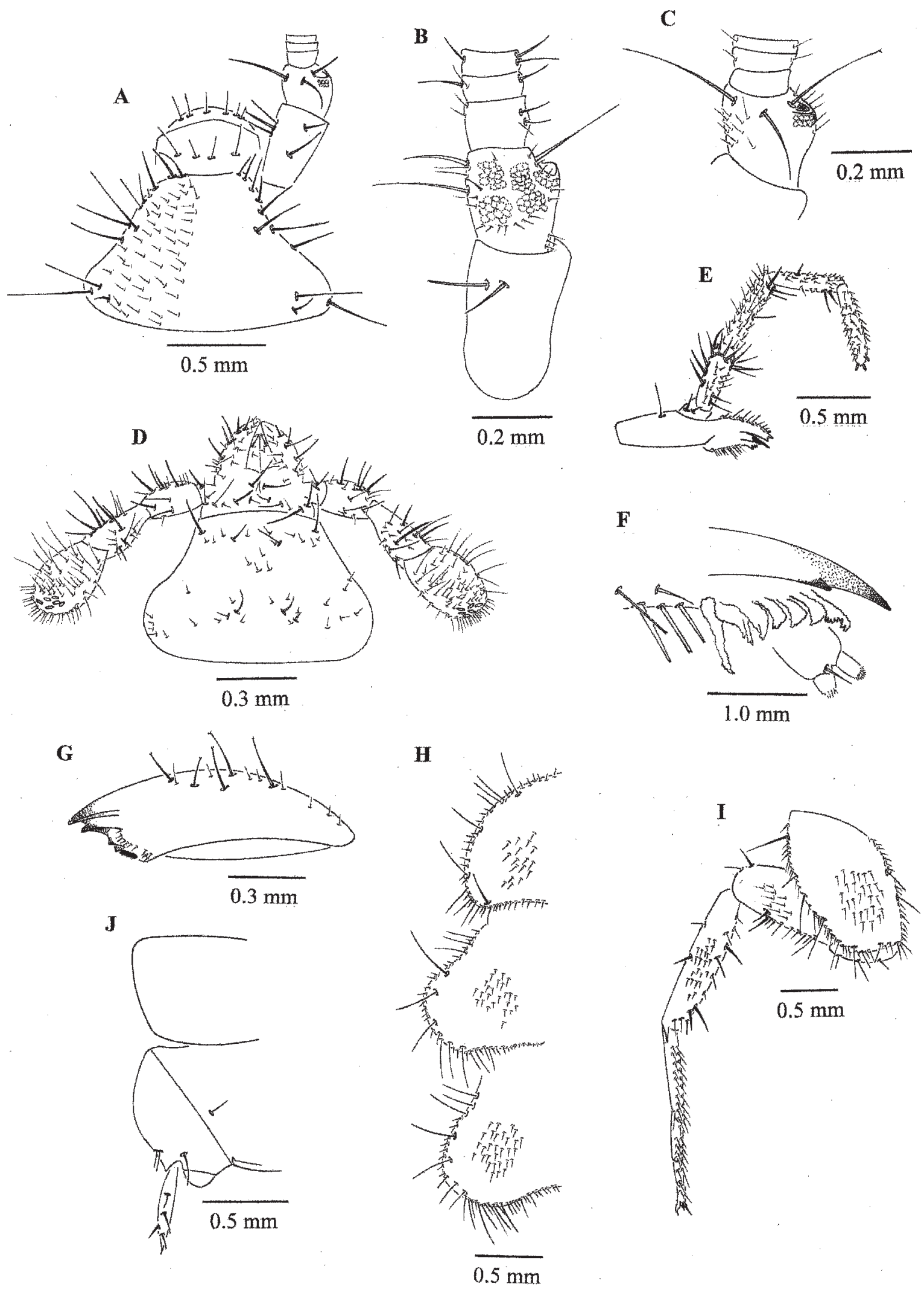

Figure 2. Speleonycta anachoretes n. sp. Male holotype from Kartchner Caverns. A, head and antennae; B, basal portion of antennae, ventral view; $C$, pedicellus, dorsal view; $D$, labium; $E$, maxilla; $F$, apex of maxilla; $G$, mandible; $H$, thoracic nota; I, hind leg; J, urosterna I and II. 
A

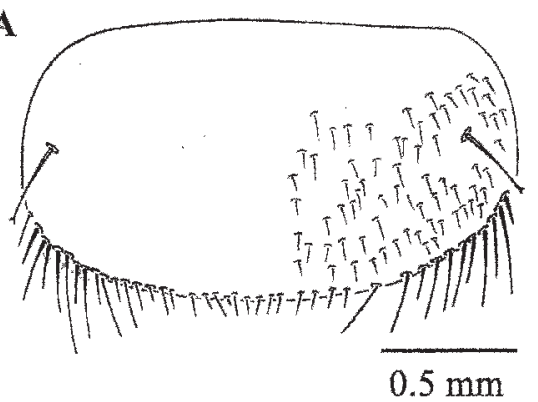

C

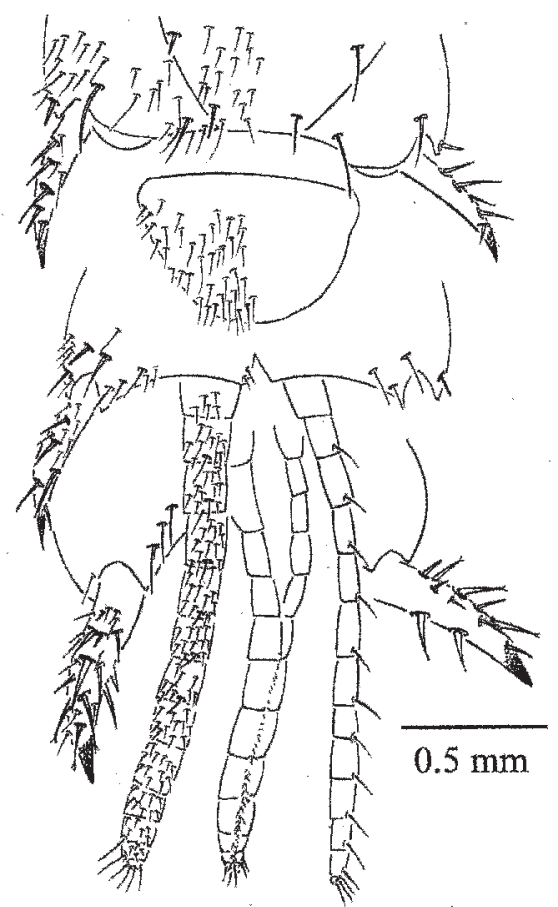

B

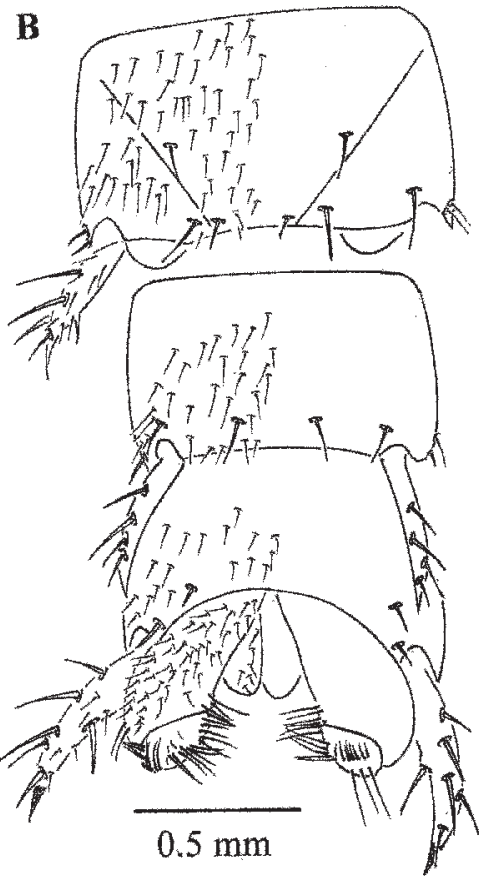

\author{
$\mathbf{D}$
}

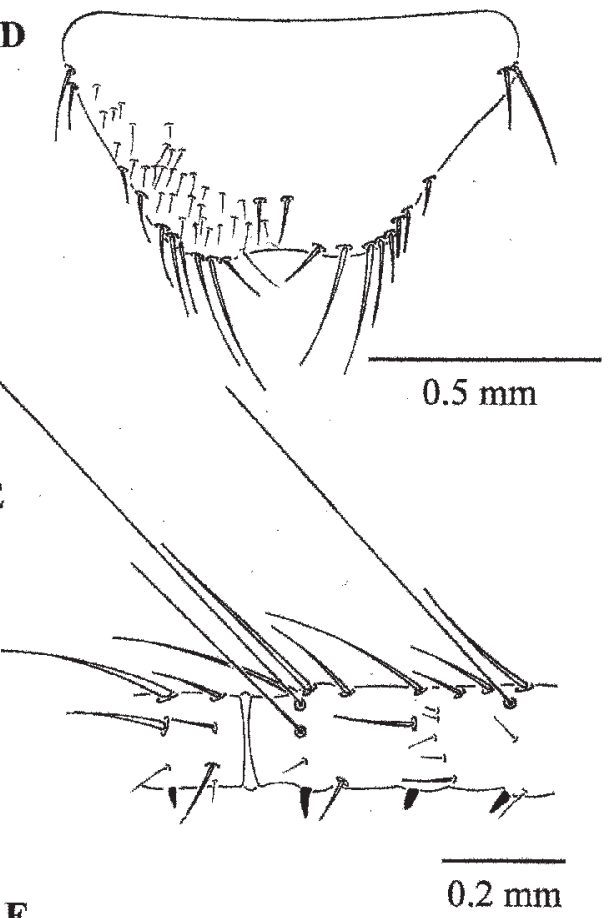

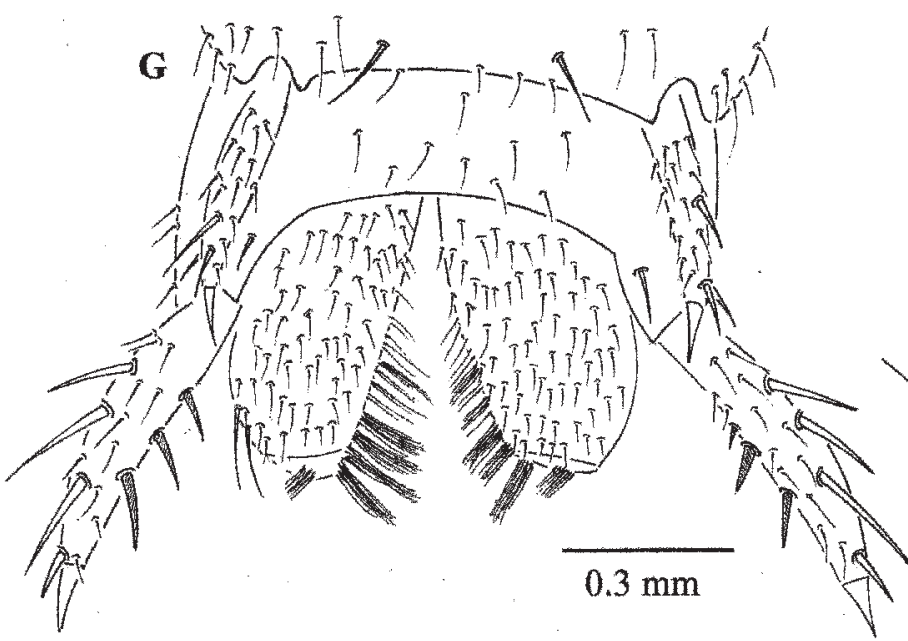

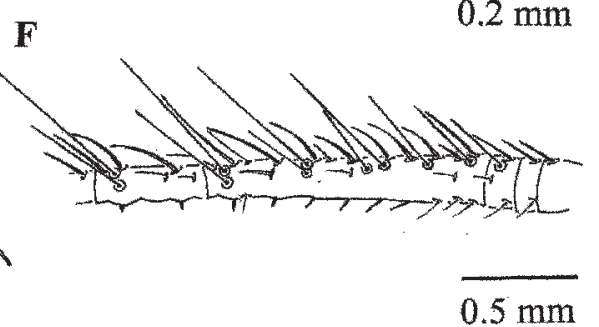

Figure 3. Speleonycta anachoretes n. sp. A-B, D-F, male holotype from Kartchner Caverns; C, female paratype from Kartchner Caverns; G, male Speleonycta sp. from Arkenstone Cave. Note that parts B and G are shown at different scales; the size of specimens from both localities are actually similar. A, uroterguite III; B, genital area of male; C, genital area of female; D, urotergite X; E, spines on cercus; F, cercus; G, paramera and stylets IX. 
inner macrochaetae about equal to the distance between them.

Cerci of adult male straight, basally with two or three annuli slightly wider than long, followed by a very long annulus and many subequal annuli. The very long annuli and the first of the subequal annuli with small sensory pegs. Pegs start as sclerotized chaetae and progressively become thicker (Figs. 3E-F). Cerci with long trichobothria (Fig. 3E). Appendix dorsalis without sensory pegs. Female cercus and appendix dorsalis simple.

Subgenital plate of female rounded to sub-parabolic (Fig. 3C). In the largest adult female $(15 \mathrm{~mm})$ and in females measuring 10.5 and $9.9 \mathrm{~mm}$ long the ovipositor surpasses apex of stylets IX by half the length of stylets (Fig. 3C), but in the $11 \mathrm{~mm}$ female it surpasses by a full length of the stylets. Gonapophyses with about 13 annuli.

\section{Postembryonic Development}

Males 12.7, 9.4, and $7.5 \mathrm{~mm}$ long had pedicellus with unicellular glands and the distinct blade-like cusp, paramera attaining about half the length of stylets IX, and small spines on cerci. Pedicellus of males 6.5 and $6.2 \mathrm{~mm}$ long had a few unicellular glands and the blade-like cusp was just beginning to form. The paramera attain one third the length of stylets IX and no spines on cerci.

Length of ovipositor in the four females of $15,11,10.5$, and $9.9 \mathrm{~mm}$ long varied between surpassing the stylets IX by half to one times the length of the stylets, and gonapophysis had about 13 annuli. In the juvenile female $(5 \mathrm{~mm})$, the ovipositor is just barely beginning to form.

\section{Etymology}

The species name anachoretes is Greek, meaning "one that retired from the world" (a hermit or recluse), in allusion to living a rather isolated existence without much competition from other species. The species inhabits nutrient-poor environments in caves where few other species can survive. An adjective.

\section{Remarks}

Speleonycta anachoretes has the diagnostic characters of the genus: no scales, urosternum VIII of male flat posteriorly, without emarginations or projections in between the stylets of this segment, and paramera with very long and specialized chaetae and a distal semieversible vesicle.

Speleonycta anachoretes shares with $S$. ozarkensis, the only other described species in the genus, the distinctive blade-like cusp with unicellular glands on the pedicellus of adult males, abdominal terga with $1+1$ distinct macrochaetae within the surface of the terga, and stylets IX stout with a robust terminal spine. The two species can be easily differentiated by the ovipositor of females. In $S$. anachoretes, females up to $15 \mathrm{~mm}$ long have a short ovipositor that surpasses stylets IX by half to one times the length of the stylets and have about 13 annuli on the gonapophyses. In the largest described female of $S$. ozarkensis, despite being smaller $(12 \mathrm{~mm})$, the ovipositor is longer $(2 \times$ the length of stylets) and gonapophysis is more subdivided (15 to 16 annuli). Males of $S$. anachoretes also have proportionally smaller paramera; the paramera of males 7.5 to $12.7 \mathrm{~mm}$ long attain about half the length of stylets IX, while in $S$. ozarkensis, males $11 \mathrm{~mm}$ long have distinctly longer paramera that attain the apex of the stylets.

Speleonycta anachoretes can furthermore be differentiated from $S$. ozarkensis by its proportionally shorter last article of the maxillary palps in large individuals (slightly longer than penultimate article versus $1.5 \times$ in S. ozarkensis), less macrochaetae on mandibles (5 to 6 versus 7), and longer legs (hind tibia about $5 \times$ longer than wide versus $3.5 \times$ ). Finally, the tibia of the second leg in the male holotype of $S$. ozarkensis is very stout $(2 \times$ longer than wide) and has a large bulge with 3 distinctly long, sclerotized, and curved macrochaetae. These modifications are apparently absent in the new species.

\section{DisCUSSION}

Currently, observations of $S$. anachoretes have been mostly confined to the easternmost passages of Kartchner Caverns. Welbourn (1999) found them near the entrance of the Red River Passage. We found them primarily in the Jackrabbit Gallery and in the vicinity of the Tarantula Room. These three sites are in the same general area and adjoin the Big Room, one of the two large sections shown to tourists at Kartchner Caverns. A single specimen observed in the interior of the Big Room may represent a vagrant animal. Two specimens have also been found in the Granite Dells section of the cave. This area is approximately $275 \mathrm{~m}$ west of the Tarantula Room and is not directly connected by humanly accessible cave passage. Both areas are equally close (approximately $15 \mathrm{~m}$ ) to the surface of the hill containing the cave and near areas where there is an interface of epigean and hypogean environments. So far, the nicoletiids at Kartchner Caverns appear to inhabit the periphery of the cave and have not been found deep in the interior. This is in sharp contrast with the long-term observation data of a population of Speleonycta occupying Arkenstone Cave, located in the Rincon Mountains, $36 \mathrm{~km}$ northwest of Kartchner Caverns. There, the animals occur only in the deeper reaches of the cave. Regardless of their apparent habitat differences, the Arkenstone specimens do not appear to be more troglomorphic than those at Kartchner. For example, the length of the legs is the same (hind tibia about $5 \times$ longer than wide and slightly shorter than the tarsus) at both localities.

Despite their proximity, both caves are in isolated karst areas with no possible connection between the caves. Due to the spatial separation of the populations and since both appear to be cave adapted, one might expect them to be different species. However, similar situations exist with other cave-inhabiting invertebrates in southern Arizona, 
where species occur in caves in widely separated, isolated karst areas with no underground connection. An example is Sitalcina peacheyi (Opiliones: Laniatores), a troglophilic harvestman, which is recorded from the Baboquivari, Santa Rita, and Rincon Mountains (Ubick and Briggs, 2008). Additionally, our examination of the only two available specimens from Arkenstone Cave revealed no distinctive morphological characteristic that would readily separate the populations as distinct species. It remains to be determined whether the Arkenstone population is a distinct species or not.

Regional desertification (drying and warming) of the northern Chihuahuan and Sonoran deserts began at the end of the Wisconsin glacial episode about $11 \mathrm{ka}$, and reached its current condition about $4 \mathrm{ka}$ (Van Devender, 1990). Conceivably, a single widely-occurring nicoletiid species may have been present in the region prior to desertification, when the climate was wetter and cooler. The species would likely have occupied both epigean (surface) and hypogean (subsoil and cave) habitats, with gene flow between populations during those times. Desertification likely resulted in extirpation of the epigean populations. The cave populations would have been isolated by intervening inhospitable hot, dry terrain, preventing gene flow between any remaining populations. Extant cave populations in the region today may thus represent relictual populations of the historic species. Obtaining fresh samples from Arkenstone Cave to sequence their DNA could help resolve whether both populations represent a single species or two troglobitic sister species, and if the latter is the case, the timing of their separation.

Speleonycta anachoretes is currently the largest troglobite documented from Kartchner Caverns and arguably one of the most interesting. It is a prime example of an organism displaying traits of cave adaptation: blind, albino, with long appendages and sensory structures. Its distinctive morphology can make it alluring not only to scientists, but also to the general public who come to visit Kartchner Caverns. At the same time, it highlights their fragility and the need for their conservation.

Our observations indicate that the nicoletiids appear to inhabit a core area around the Jackrabbit Gallery that is located about 15 meters from the developed tourist trail. Very rough estimates indicate that this small gallery could support a population of around one hundred nicoletiids, since there were about two individuals per square meter in this area. One of the nicoletiids was caught less than one meter from a large spotlight that fully illuminated the area. The presence of light does not appear to disturb the animals.

What is the size of the nicoletiid population at Kartchner Caverns? This is an extremely difficult question to answer with the data currently available, and only a very vague estimate can be provided at this time. The Jackrabbit Gallery represents less than one percent of the total mapped length of the cave, and this area is estimated to harbor up to a hundred individuals. Furthermore, there are many areas within the cave that are, due to their small size, inaccessible to man, but which are accessible to nicoletiids. These areas are not represented by the mapped portion of the cave, and because they are inaccessible to humans, their extent can only be surmised. Even if other areas of the cave have much lower densities of nicoletiids than the Jackrabbit Gallery, it is probably safe to assume that the total population for the cave is at least in the hundreds.

The commercial development of Kartchner Caverns for tourism does not appear to have adversely affected the nicoletiid population. They appear to cope well with the conditions of illumination and limited human use of their habitat. In the center of Jackrabbit Gallery there is an environmental monitoring station, one of a series of such stations placed throughout the cave that are used by park rangers to check cave microclimatic conditions on a regular basis. Despite routine visits by the park staff to this area over the years, the species has persisted. Additionally, the development of the cave included the boring of a horizontal access tunnel (Tarantula Tunnel) within what we now consider to be the core habitat area of the species in the cave. Furthermore, a vertical shaft (Jackrabbit Shaft) was drilled down from the surface to provide an escape route for construction personnel and for the moving of materials into the cave prior to completion of the tunnel access. This shaft is right in the heart of the nicoletiid habitat, and over the years of cave construction caused extensive human traffic and movement of equipment and supplies through the area. Nevertheless, the gross numbers of animals observed in our study are within an order of magnitude of those observed in Welbourn's study twenty years ago. If anything, we are finding more animals now.

But the cautionary principle has to be used when considering conservation issues for the species in the cave. Neither Welbourn's nor our study has been designed to provide a quantitatively accurate assessment of the health of the population, nor can we confidently state whether the population has decreased or increased since the commercial development of the cave.

\section{ACKNOWLEDGMENTS}

We thank Robert R. Casavant, Research and Science Manager, Arizona State Parks. He has been instrumental in developing the arthropod re-inventory project at Kartchner Caverns. He has provided support at every stage of our field work, including crawling with us to the narrow recesses of the cave. His kindness, humor, and willingness to help and support our effort have not only made this project a reality, but a joy. We thank Steve Willsey, the principal ranger assigned to our project, who has been present on each of our research trips. Steve's knowledge of the cave and keen interest in the project has made him an indispensable asset. He has developed a sharp 
eye for small, crawling things. We also thank park rangers Abe Randolph, Mary Kumiega, and Jon Lauderbaugh, who have accompanied us on some of our trips, and other park personnel that have helped make the project a success.

We thank Carl Olson of the University of Arizona, Department of Entomology for reviewing the manuscript. Travel expenses for one of us (LE) and three of his students (Terrence Turner, Alanna Henneberry, and Michael Mormando) were supported by a VPAA Grant from Marist College. Molecular work was supported by the School of Science at Marist College, and the assistance of students of the Spring 2010 Genetics Course (BIO320).

\section{REFERENCES}

Espinasa, L., Furst, S., Allen, T., and Slay, M.E., 2010, A new genus of the subfamily Cubacubaninae (Insecta: Zygentoma: Nicoletiidae) from caves in south-central and southwestern USA: Journal of Cave and Karst Studies, v. 72, no. 3, p. 161-168, doi: 10.4311/jcks20091sc0097.
Espinasa, L., and Giribet, G., 2009, Living in the dark-species delimitation based on combined molecular and morphological evidence in the nicoletiid genus Texoreddellia Wygodzinsky, 1973 (Hexapoda: Zygentoma: Nicoletiidae) in Texas and Mexico, in Cokendolpher, J.C., and Reddell, J.R., eds., Studies on the Cave and endogean Fauna of North America, Part V: Austin, Texas Memorial Museum Speleological Monograph 7, p. 87-110.

Jagnow, D.H., 1999, Geology of Kartchner Caverns, Arizona: Journal of Cave and Karst Studies, v. 61, no. 2, p. 49-58.

Tufts, R., and Tenen, G., 1999, Discovery and history of Kartchner Caverns, Arizona: Journal of Cave and Karst Studies, v. 61, no. 2, p. 44-48.

Ubick, D., and Briggs, T.S., 2008, The harvestman family Phalangodidae. 6. Revision of the Sitalcina Complex (Opiliones: Laniatores): Proceedings of the California Academy of Sciences, ser. 4, v. 59, no. 1, p. $1-108$.

Van Devender, T.R., 1990, Late Quaternary vegetation and climate of the Chihuahuan Desert, United States and Mexico, in Betancourt, J.L., Van Devender, T.R., and Martin, P.S., eds., Packrat Middens: The Last 40,000 years of Biotic Change: Tucson, University of Arizona Press, $467 \mathrm{p}$.

Welbourn, W.C., 1999, Invertebrate cave fauna of Kartchner Caverns, Kartchner Caverns, Arizona: Journal of Cave and Karst Studies, v. 61 , no. 2 , p. $93-101$. 